\title{
SUDOITE IN SOME VISEAN (LOWER CARBONIFEROUS) K-BENTONITES FROM BELGIUM
}

\author{
A. ANCEAU \\ Laboratoire de Géologie des Argiles, Université de Liège, Allée du 6 Août B 18, B-4000 Liège, Belgique
}

(Received 29 November 1991; revised 23 March 1992)

\begin{abstract}
Sudoite occurs as a cryptocrystalline clay in some Visean K-bentonites from Belgium. Usually associated with illite-smectite mixed-layers, this chlorite has been found locally as a monomineralic clay component of a K-bentonite bed. The mineral has a composition close to $\left(\mathrm{Al}_{3} \mathrm{Mg}_{2}\right)\left(\mathrm{Si}_{3} \mathrm{Al}\right) \mathrm{O}_{10}(\mathrm{OH})_{8}$. The cell parameters have been calculated from the diffractogram using the space group $C 2 / m\left(a=5.228, b=9.056, c=14.326 \AA, \beta=97^{\circ} 00^{\prime}, d(060)=1.509 \AA\right)$. The polytype corresponds to a $I b$ structure. Some hypotheses are proposed for the origin of this chlorite. The coexistence of sudoite and pyrite could explain why the chlorite present in Visean K-bentonites is not a Fe-rich species typical of diagenetic conditions, but a Fe-poor one.
\end{abstract}

Numerous K-bentonite beds, intercalated in the Visean limestones (Upper Dinantian, Lower Carboniferous) of Belgium, occur across the Namur and Dinant synclinoria. A detailed investigation of the clay fraction $(<2 \mu \mathrm{m})$ shows the presence of ordered illitesmectite (I-S) mixed-layer minerals, illite (containing $\sim 3 \%$ of swelling layers, according to Eberl \& Velde's method, 1989), kaolinite and Al-rich chlorites. Two types of Al-rich chlorite have been identified in these K-bentonites: sudoite and a donbassite-like mineral. Whereas "donbassite" has been detected only by electron microprobe analysis (this occurrence will be described in another paper), abundant sudoite was identified by X-ray diffraction (XRD).

Aluminium-rich chlorites have been identified in many environments, namely hydrothermal alteration zones, sediments, soils, veins, and low-grade metamorphic rocks. Reviews of these occurrences by Fransolet \& Bourguignon (1978) and Percival \& Kodama (1989) show that the species names designating these minerals were fraught with ambiguity until the report of the AIPEA Nomenclature Committee (Bailey et al., 1979; Bailey, 1980a).

Sudoite, ideally $\mathrm{Al}_{2}\left(\mathrm{Si}_{3} \mathrm{Al}\right) \mathrm{O}_{10}(\mathrm{OH})_{2}\left(\mathrm{Mg}_{2} \mathrm{Al}\right)(\mathrm{OH})_{6}$, is a chlorite in which the $2: 1$ layer is dioctahedral and the interlayer hydroxide sheet is trioctahedral (Bailey et al., 1979; Bailey, 1980a). In this di,trioctahedral chlorite, tetrahedral $\mathrm{Al}$ is known to range from $\sim 0 \cdot 4-1 \cdot 1$ atoms per formula unit, octahedral $\mathrm{Al}$ from $2 \cdot 5-3 \cdot 4$, and $\mathrm{Mg}$ from $1 \cdot 2-2 \cdot 5$. Total octahedral occupancy ranges from $4 \cdot 5-5 \cdot 1$ atoms per $6 \cdot 0$ available sites (Bailey \& Lister, 1989) (Table 1). Donbassite, a dioctahedral chlorite, is dioctahedral in both the $2: 1$ layer and the interlayer hydroxide sheet. For a variable amount $(x)$ of tetrahedral substitution, the formula can be written as $\mathrm{Al}_{2}\left(\mathrm{Si}_{4 x} \mathrm{Al}_{x}\right) \mathrm{O}_{10}(\mathrm{OH})_{2} \mathrm{Al}_{2+x / 3}(\mathrm{OH})_{6}$. Tetrahedral $\mathrm{Al}$ ranges from $0 \cdot 6-1 \cdot 3$ atoms per $4 \cdot 0$ positions and the octahedral cation total is between $4 \cdot 2$ and $4 \cdot 5$ atoms per 6.0 sites (Bailey \& Lister, 1989). Dioctahedral and di,trioctahedral chlorites are characterized by an intense 003 reflection at $4.70 \AA$ and $d(060)$ between 1.49 and $1.51 \AA$.

In Belgium, sudoite has been described at Ottré in quartz veins cross-cutting low-grade metapelites of the Cambro-Tremadocian Stavelot Massif (Fransolet \& Bourguignon, 1978; 
TABLE 1. Schematic classification of the chlorite group (after Bailey 1980a,b; Bailey, 1988; Ahn \& Buseck, 1988).

\begin{tabular}{llcc}
\hline \multicolumn{1}{c}{ Subgroup } & \multicolumn{1}{c}{ Species } & $n\left(*^{*}\right)$ & $d(060)$ in $\AA$ \\
\hline Dioctahedral chlorite & $\begin{array}{c}\text { donbassite: } \\
\mathrm{Al}_{4+x / 3}\left(\mathrm{Si}_{4-x} \mathrm{Al}_{x}\right) \mathrm{O}_{10}(\mathrm{OH})_{8} \\
\text { Di,trioctahedral chlorite }\end{array}$ & $4 \cdot 0-4 \cdot 5$ & $1 \cdot 49-1.50$ \\
Trioctahedral chlorite & $\begin{array}{c}\left(\mathrm{LiAl}_{4}\right)\left(\mathrm{Si}_{3} \mathrm{Al}\right) \mathrm{O}_{10}(\mathrm{OH})_{8} \\
\text { sudoite: } \\
\left(\mathrm{Al}_{3} \mathrm{Mg}_{2}\right)\left(\mathrm{Si}_{3} \mathrm{Al}\right) \mathrm{O}_{10}(\mathrm{OH})_{8} \\
\text { clinochlore: } \\
\left(\mathrm{Mg}_{5} \mathrm{Al}\right)\left(\mathrm{Si}_{3} \mathrm{Al}\right) \mathrm{O}_{10}(\mathrm{OH})_{8} \\
\text { chamosite: } \\
\left(\mathrm{Fe}_{5}^{2+} \mathrm{Al}\right)\left(\mathrm{Si}_{3} \mathrm{Al}\right) \mathrm{O}_{10}(\mathrm{OH})_{8}\end{array}$ & $\sim 5.0$ & $1.49-1.51$ \\
\hline
\end{tabular}

$\left({ }^{*}\right) n=$ octahedral cation total per formula unit.

Fransolet \& Schreyer, 1984). Although the presence of sudoite associated with I-S mixedlayers has been noted in the Ordovician K-bentonite beds of the eastern United States (Weaver, 1959, 1989), the identification of sudoite in the Visean K-bentonites constitutes a new mode of occurrence in Belgium.

The purpose of this paper is to describe the mineralogical properties and to discuss conditions of formation of sudoite in the K-bentonites of Belgium.

\section{GEOLOGICAL SETTING AND CLAY MINERALOGICAL CHARACTERISTICS OF THE K-BENTONITES}

The Visean limestones of the Namur and Dinant synclinoria (South of Belgium) have been deposited on an epicontinental platform and are mainly composed of sequential limestones ranging from subtidal to supratidal facies. Numerous $\mathrm{K}$-bentonite beds are interbedded in the Middle and Upper Visean limestones (Thorez \& Pirlet, 1978); they have a thickness varying from a few to fifty $\mathrm{cm}$ and are considered to be volcanic in origin.

The K-bentonites seldom have a monomineralic clay composition. The clay assemblages are predominantly ordered I-S mixed-layers with R1 and R3 types of ordering (Śrcdoń, 1984; Środoń \& Eberl, 1984; Moore \& Reynolds, 1989) associated with Al-rich chlorite(s) and/or kaolinite. The proportion of expandable layers in the I-S associated with the Al-rich chlorite(s) usually varies from $12 \%$ (R3 ordering) to $30 \%$ (R1 ordering). Locally, sudoite has been found associated with an open illite.

A detailed XRD investigation of more than three hundred samples in several areas of southern Belgium shows significant variations of composition: locally, the bentonitic clay may be a pure sudoite but, laterally and/or vertically in the same bed, it is mixed with I-S either as a minor or a major component.

A K-bentonite bed of Upper Visean age (V3b $\alpha, \mathrm{Cf} 6 \alpha$ foraminifera subzone, Conil et al., 1977), located in the quarry at Anhée (Fig. 1), is locally composed of pure sudoite. Laterally, an I-S may occur in small amounts. The percentage of expandable layers in the I-S within the underlying $\mathrm{K}$-bentonite beds is $\sim 13 \% \mathrm{~S}$ ( $\mathrm{R} 3$ ordering). In this $\mathrm{K}$-bentonite, the sudoite is accompanied by quartz and iron oxides (goethite). Iron oxides are produced at the present time by weathering of the original pyrite and stain the bentonite to a tan 


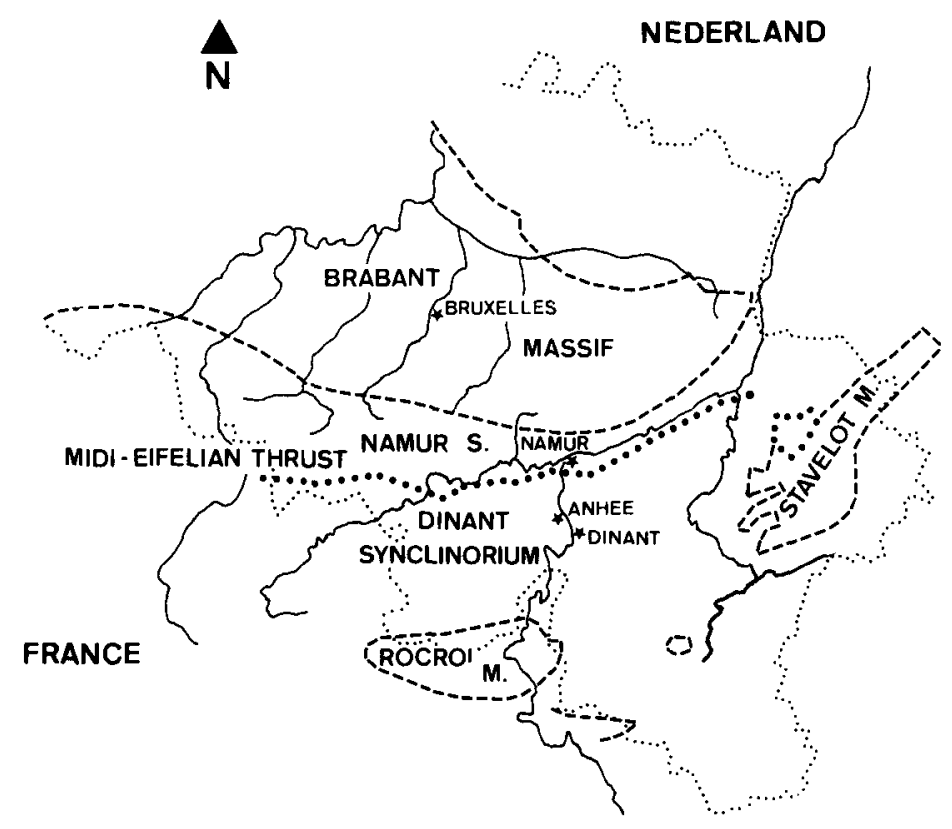

Fig. 1. Sample location.

colour. Sudoite from Anhée (sample $\mathrm{Kb} 227$ ) has been selected for structural and chemical analyses.

\section{CRYSTALLOGRAPHIC PROPERTIES}

\section{Powder method-unit-cell parameters}

The sample $\mathrm{Kb} 227$, bearing sudoite, was gently crushed and finely ground. The diffractogram of the bulk fraction was recorded with a Philips diffractometer using monochromatic Fe- $K \alpha$ radiation, a scanning rate of $0.5^{\circ} 2 \theta / \mathrm{min}$, and $1^{\circ}-0.2 \mathrm{~mm}-1^{\circ}$ slits. Quartz present in the sample was used as an internal standard. The corrected X-ray powder diffraction data are presented in Table 2 . The relative intensities were obtained by direct measurements on the diffractogram using the $4.74 \AA$ reflection as $100 \%$ intensity. Indexation of the powder pattern in the space group $C 2 / m$ is based on the data of Eggleton \& Bailey (1967) and Fransolet \& Bourguignon (1978). Both the observed intensities and the $d(060)$ at $1.509 \AA$ indicate the di,trioctahedral nature of the chlorite (Table 1$)$. The unit-cell dimensions, calculated with the refinement program of Appleman \& Evans (1973) are: $a=5.228(1), b=9.056(2), c=14.326(5) \AA$ and $\beta=97^{\circ} 00^{\prime}\left(2^{\prime}\right)$.

Eggleton \& Bailey (1967) determined that sudoite in the Tracy mine deposits has a $I I b$ layer polytype. Lin \& Bailey (1985) confirmed the $I I b$ arrangement for the Ottre sudoite by using a single-crystal method. The grain size of sudoite from the Anhée K-bentonite does not permit proper identification of the layer stacking. However, comparison of the values and intensities for $20 l$ reflections with the data of Eggleton \& Bailey (1967) and Bailey \& Lister (1989) suggests that the sudoite in sample $\mathrm{Kb} 227$ is also a $I I b$-layer polytype. 
TABLE 2. X-ray powder diffraction data for Visean sudoite.

\begin{tabular}{|c|c|c|c|}
\hline$h k l$ & I/lo & $d_{\text {obs }}(\AA)$ & $d_{\text {calc }}(\AA)$ \\
\hline 001 & 25 & $14 \cdot 333$ & $14 \cdot 219$ \\
\hline 002 & 45 & $7 \cdot 115$ & $7 \cdot 110$ \\
\hline 003 & 100 & 4.739 & $4 \cdot 740$ \\
\hline 110 & 75 & $4 \cdot 502$ & $4 \cdot 503$ \\
\hline 004 & 55 & $3 \cdot 555$ & $3 \cdot 555$ \\
\hline 005 & 20 & $2 \cdot 840$ & $2 \cdot 844$ \\
\hline $13 \overline{1}\}$ & \multirow{2}{*}{10} & \multirow{2}{*}{$2 \cdot 599$} & $\{2.595$ \\
\hline 200$\}$ & & & $2 \cdot 595$ \\
\hline $13 \underline{1}$ & \multirow{2}{*}{30} & \multirow{2}{*}{2.537} & $2 \cdot 539$ \\
\hline $20 \overline{2}$ & & & 2.539 \\
\hline $13 \overline{2}\{$ & \multirow{2}{*}{75} & \multirow{2}{*}{$2 \cdot 498$} & $\int 2 \cdot 500$ \\
\hline 201$\}$ & & & 2.499 \\
\hline 132$\}$ & \multirow{2}{*}{30} & \multirow{2}{*}{$2 \cdot 403$} & $\{2 \cdot 402$ \\
\hline $20 \overline{3}\}$ & & & $\{2 \cdot 403$ \\
\hline 006 & 15 & $2 \cdot 362^{*(1)}$ & - \\
\hline 202$\}$ & \multirow{2}{*}{20} & \multirow{2}{*}{$2 \cdot 346$} & $\{2.347$ \\
\hline $13 \overline{3}\}$ & & & $\{2 \cdot 347\}$ \\
\hline 007 & 10 & $2 \cdot 030$ & $2 \cdot 031$ \\
\hline $13 \overline{5}$ & 25 & $1.988^{*(2)}$ & - \\
\hline $20 \overline{6}\}$ & \multirow{2}{*}{10} & \multirow{2}{*}{1.865} & $\{1 \cdot 867$ \\
\hline 135$\}$ & & & $\{1 \cdot 866$ \\
\hline $20 \overrightarrow{7}$ & 15 & 1.705 & 1.704 \\
\hline $20 \overline{8}\}$ & \multirow{2}{*}{20} & \multirow{2}{*}{1.558} & $\int 1.558$ \\
\hline 137$\}$ & & & $\{1.557$ \\
\hline $33 \overline{1}$ & \multirow{3}{*}{40} & \multirow{3}{*}{1.509} & $\{1.509$ \\
\hline 060$\}$ & & & $1 \cdot 509$ \\
\hline 062$]$ & & & $\int 1.476$ \\
\hline 331$\}$ & \multirow[t]{2}{*}{10} & \multirow[t]{2}{*}{1.476} & $\{1 \cdot 476$ \\
\hline $33 \overline{3}$ & & & 1.477 \\
\hline 063\{ & \multirow{2}{*}{5} & \multirow{2}{*}{1.439} & $\int 1.438$ \\
\hline 332$\}$ & & & $\{1.438$ \\
\hline 00,10 & 5 & $1 \cdot 419^{*}$ & - \\
\hline
\end{tabular}

Diffractogram with monochromatic $\mathrm{Fe}-K \alpha$ radiation and corrected using quartz as internal standard.

* $d$ values not used for indexation.

${ }^{1}$ Shoulder.

${ }^{2}$ Undetermined because of presence of quartz.

\section{Oriented aggregates}

The sudoite-rich sample was crushed and dispersed in distilled water. The $<2 \mu \mathrm{m}$ fraction, separated by combined sedimentation and centrifugation, was prepared as an oriented aggregate by sedimentation on to a slide. The diffractogram $\left(2-30^{\circ} 2 \theta\right)$ was recorded on a Philips diffractometer using monochromatic $\mathrm{Cu}-K \alpha$ radiation, a scanning rate of $2^{\circ} 2 \theta / \mathrm{min}$, and $1^{\circ}-0.2 \mathrm{~mm}-1^{\circ}$ slits. The $00 \mathrm{l}$ reflections, observed in the air-dried state, do not shift after ethylene glycol solvation and after heating at $500^{\circ} \mathrm{C}$. Thus, the mineral is not a mixed-layer chlorite mineral or a swelling chlorite. In the air-dried state, the most intense reflection is the 003 whereas the 001 reflection is the weakest. After ethylene glycol solvation, the relative intensities of the $00 l$ reflections are not modified. After heating 
at $500^{\circ} \mathrm{C}$ for $4 \mathrm{~h}$, the intensities of the $00 \mathrm{l}$ reflections of sudoite change: the 001 reflection increases in intensity by a factor of five whereas the intensities of the high orders $00 l$ decrease markedly.

\section{CRYSTAL CHEMISTRY}

\section{Chemical composition}

Chemical analysis was performed on $0.4 \mathrm{~g}$ of the bulk Kb 227 sample after drying for $2 \mathrm{~h}$ at $105^{\circ} \mathrm{C} ; \mathrm{Al}, \mathrm{Ti}, \mathrm{Fe}, \mathrm{Ca}, \mathrm{Mg}, \mathrm{Mn}, \mathrm{Li}, \mathrm{K}$ and $\mathrm{Na}$ were measured by atomic absorption using a Perkin Elmer 603 spectrophotometer. Total Si, quartz content (Dixon \& Jackson, 1960), and loss-on-ignition were determined by gravimetry. Ferrous and ferric iron were determined by potentiometry using the method of Ungethüm (1965). The chemical analysis is presented in Table 3.

The $\mathrm{Kb} 227$ sample contains $24 \cdot 11 \%$ quartz. The percentage of iron oxide corresponds to the difference between total Fe analysed before and after removal by Mehra \& Jackson's method (1960) which dissolved $1 \cdot 80 \% \mathrm{Fe}_{2} \mathrm{O}_{3}$ which was attributed to goethite. The $\mathrm{TiO}_{2}$ content was assigned to anatase because although it was not detected by XRD because of its small amount $(0 \cdot 43 \%)$, it is known to occur in other Visean K-bentonites.

As sudoite does not theoretically contain any $\mathrm{Ca}, \mathrm{Na}$ and $\mathrm{K}$, these cations might indicate the presence of impurities in the sample, also not detectable by XRD. Corrections to the analysis were made for calcite, biotite (with $\mathrm{Mg} / \mathrm{Fe}=1$ ) and paragonite contaminants assuming a theoretical composition.

TABLE 3. Chemical data for Anhée sudoite (bulk rock analysis) and sudoite from Ottré.

\begin{tabular}{|c|c|c|c|c|c|c|}
\hline & $\begin{array}{c}(1) \\
\text { Chemical } \\
\text { analysis of } \\
\mathrm{Kb} 227\end{array}$ & \multicolumn{2}{|c|}{$\begin{array}{c}(2) \\
\text { Chemical treatments }\end{array}$} & \multirow[t]{2}{*}{ (3) } & \multirow[t]{2}{*}{ (4) } & \multirow[t]{2}{*}{$\begin{array}{c}(5) \\
\text { Ottré }\end{array}$} \\
\hline & & quartz & goethite & & & \\
\hline $\mathrm{SiO}_{2}$ & $50 \cdot 07$ & $24 \cdot 11$ & & $35 \cdot 70$ & $3 \cdot 24$ & 33.06 \\
\hline $\mathrm{Al}_{2} \mathrm{O}_{3}$ & $24 \cdot 37$ & & & $33 \cdot 77$ & $3 \cdot 61$ & $35 \cdot 74$ \\
\hline $\mathrm{CaO}$ & 0.46 & & & - & - & - \\
\hline $\mathrm{TiO}_{2}$ & 0.43 & & & - & - & - \\
\hline $\mathrm{Fe}_{2} \mathrm{O}_{3}$ & $3 \cdot 81$ & & $1 \cdot 80$ & $2 \cdot 81$ & 0.19 & $2 \cdot 74$ \\
\hline $\mathrm{FeO}$ & 0.41 & & & 0.35 & $0 \cdot 03$ & $0 \cdot 24$ \\
\hline $\mathrm{MnO}$ & 0.03 & & & 0.04 & $0 \cdot 003$ & 0.28 \\
\hline $\mathrm{MgO}$ & $9 \cdot 57$ & & & $13 \cdot 26$ & $1 \cdot 79$ & 14.09 \\
\hline $\mathrm{Na}_{2} \mathrm{O}$ & 0.03 & & & - & - & - \\
\hline $\mathrm{K}_{2} \mathrm{O}$ & 0.07 & & & - & - & - \\
\hline $\mathrm{Li}_{2} \mathrm{O}$ & 0.04 & & & 0.06 & 0.02 & - \\
\hline Ign. loss. & $10 \cdot 62$ & & 0.20 & $14 \cdot 00$ & & $13 \cdot 85$ \\
\hline Total & 99.91 & & & $100 \cdot 00$ & & $100 \cdot 00$ \\
\hline
\end{tabular}

(1)-(2): Analyst J.-M. Speetjens.

(3) : (2), $0 \cdot 82 \%$ calcite, $0.70 \%$ biotite, $0.37 \%$ paragonite, and $0 \cdot 43 \%$ anatase have been substracted from (1) and analysis recalculated to $100 \%$.

(4) : Number of cations on the basis of 28 cationic valences.

(5) : Fransolet \& Bourguignon (1978): analysis recalculated to $100 \%$, without minor $\mathrm{Zn}$, Ni and Li contents. 
The corrected chemical composition of the sudoite in Table 3 (3) is similar to the sudoite occurring in quartz veins in the Stavelot Massif (Table 3 (5), as described by Fransolet \& Bourguignon (1978)).

\section{Structural formula}

The general formula for Al-rich chlorite is: $\left(\mathrm{Al}, \mathrm{Fe}^{3+}\right)_{4-y}\left(\mathrm{Mg}, \mathrm{Fe}^{2+}\right)_{x / 2+3 y / 2}\left(\mathrm{Si}_{4-x} \mathrm{Al}_{x}\right)-$ $\mathrm{O}_{10}(\mathrm{OH})_{8}$, with $0<(x+y)<2$ (Sudo \& Sato, 1966).

The structural formula for the sample from Anhée calculated on the basis of 28 positive charges (Table 3) is: $\left(\mathrm{Al}_{2 \cdot 84} \mathrm{Mg}_{1 \cdot 79} \mathrm{Fe}_{0 \cdot 19}^{3+} \mathrm{Fe}_{0.03}^{2+} \mathrm{Li}_{0 \cdot 02}\right)\left(\mathrm{Si}_{3 \cdot 24} \mathrm{Al}_{0.76}\right) \mathrm{O}_{10}(\mathrm{OH})_{8} 0 \cdot 46 \mathrm{H}_{2} \mathrm{O}$.

For sample $\mathrm{Kb} 227,(x+y)$ is $1 \cdot 73$; the proportion of tetrahedral $\mathrm{Al}(x)$ is $0 \cdot 76$, and the total trivalent cations $(y)$ is 0.97 . The total of octahedral cations per formula unit $\mathrm{O}_{10}(\mathrm{OH})_{8}$ is 4.87; this value, close to 5 , confirms the identification of sudoite (Table 1).

For the Stavelot Massif sudoite, Fransolet \& Bourguignon (1978) also noted an excess of molecular $\mathrm{H}_{2} \mathrm{O}$, which is not due to vermiculitic layers, but strongly bound within the chlorite structure. Środon \& Eberl (1984) quote similar observations for illite, in which the extra water is not removed by conventional drying, because it may be physically or chemically sorbed on crystal edges and faces, or may exist as $\mathrm{H}_{3} \mathrm{O}^{+}$or $\mathrm{H}_{2} \mathrm{O}$ in interlayer positions.

\section{ORIGIN}

The parent materials of the Visean K-bentonite beds were volcanic ashes deposited in a marine environment (Thorez \& Pirlet, 1978). The volcanic material was affected by halmyrolysis and altered into a clayey material dominated by smectite (Weaver, 1953). During diagenesis, the smectite reacted to form a continuous series of I-S mixed-layers with an increasing proportion of I layers in response to an increasing burial depth. The basic reaction for the formation of diagenetic illite is (Hower et al., 1976):

$$
\text { smectite }+\mathrm{Al}^{3+}+\mathrm{K}^{+} \rightarrow \text { illite }+\mathrm{Si}^{4+}+\left(\mathrm{Fe}^{2+}, \mathrm{Mg}^{2+}\right)
$$

(mechanism 1). Potassium and Al are provided through decomposition of biotite and $\mathrm{K}$ feldspar, whereas the excess silica forms quartz. Chlorite can occur as a by-product of the reaction, incorporating $\mathrm{Mg}$ and $\mathrm{Fe}$ released from the parent smectite.

Microscopic investigations of thin sections of the K-bentonite from Anhée show a cryptocrystalline clay matrix composed of sudoite with various types of coarse particles and phenocrysts: mainly quartz, rare chloritized biotite (sudoite according to microprobe analysis) and weathered pyrite. Two different types of quartz occurs: isolated grains and silicified material. Typically the quartz grains show subhedral to anhedral or elongated acicular (splinters) crystals of volcanic origin. Silicification occurs as disseminated grains within the clay matrix or as elongated aggregates up to $250 \mu \mathrm{m}$ in length. Quartz proportions show significant vertical and lateral variations.

Sudoite occurring in the Visean K-bentonites as a cryptocrystalline clay matrix appeared either before or during burial diagenesis. Two reasonable hypotheses of formation can be considered: (1) transformation of a smectitic precursor (as the formation of illite in mechanism 1), and (2) in situ neoformation.

(1) Structurally, the transformation of smectite into sudoite via smectite-sudoite mixed- 
layers requires addition of $\mathrm{Al}$ and $\mathrm{Mg}$ and release of $\mathrm{Si}$. This transformation could be approximated by the reaction:

$$
\text { smectite }+\mathrm{Al}^{3+}+\mathrm{Mg}^{2+} \rightarrow \text { sudoite }+\mathrm{Si}^{4+}
$$

(mechanism 2). Comparison of the cation distribution within beidellite, montmorillonite and sudoite is presented in Table 4 . These minerals are characterized by a dioctahedral $2: 1$ layer. If the parent smectite is a montmorillonite, $\mathrm{Al}$ must be added both to the tetrahedral and octahedral sheets of the layer for the formation of sudoite. The negatively charged $2: 1$ layer is further balanced by the positively charged interlayer constituted by a trioctahedral sheet enriched in $\mathrm{Mg}$ and $\mathrm{Al}$. The $\mathrm{Mg}$ of the 2:1 layer of montmorillonite released during transformation may be located in the interlayer, but some $\mathrm{Mg}$ must come from another source. A beidellitic precursor requires less substitutions in the $2: 1$ layer than a montmorillonitic one: Al must only be added in tetrahedral position. But all the $\mathrm{Mg}$ in the interlayer of sudoite must be supplied from an external source. The silica patches observed in thin sections of the Anhée K-bentonite might correspond to the excess of silica produced during the transformation of smectite into sudoite (mechanism 2).

(2) Neoformation of sudoite requires solutions rich in $\mathrm{Si}, \mathrm{Al}$ and $\mathrm{Mg}$ but poor in Fe. These cations can be directly supplied by the alteration of volcanic material, by dissolution of smectite or another clay precursor (e.g. kaolinite), by later interstitial solutions, or by their combination. In this second case, authigenic sudoite grows from interstitial solutions migrating in the bentonite and the enclosing carbonate rocks.

The evolution of the clay matrix into sudoite might be explained by one or the two combined hypotheses. For the Anhée K-bentonite, the formation of sudoite after rare biotite cannot explain the origin of this abundant chlorite.

Chemical analyses of $\mathrm{K}$-bentonites containing sudoite show $\mathrm{Mg}$ enrichment with respect to I-S bentonites. Two different sources of $\mathrm{Mg}$ may be evoked: the bentonite and an external source. The Mg can: (a) result from alteration of the volcanic material and ferromagnesian minerals; (b) be released during the illitization of the smectitic component; (c) originate from solutions present in the enclosing carbonate rocks. The fact that sudoite occurs only locally in some K-bentonite beds suggests either that the original ash material was slightly variable in composition, or that there were variations in the $\mathrm{Mg}$ content within the enclosed sediments. Differences in the permeability between the volcanic material and the enclosing rocks could also have influenced the circulation of $\mathrm{Mg}$-rich solutions and, consequently, the final mineralogy of the K-bentonite beds. These differences are reflected by lateral and vertical variations in mineral composition. This would imply that there was

TABLE 4. Cation distribution in sudoite and smectites.

\begin{tabular}{lccc}
\hline & Sudoite & Beidellite (*) & Montmorillonite (*) \\
\hline Tetrahedral sheet & $3 \mathrm{Si}^{4+} \mathrm{Al}^{3+}$ & $(4-x) \mathrm{Si}^{4+} x \mathrm{Al}^{3+}$ & $4 \mathrm{Si}^{4+}$ \\
Octahedral sheet & $4 \mathrm{Al}^{3+}$ & $4 \mathrm{Al}^{3+}$ & $2(2-y) \mathrm{Al}^{3+} 2 y \mathrm{Mg}^{2+}$ \\
Tetrahedral sheet & $3 \mathrm{Si}^{4+} \mathrm{Al}^{3+}$ & $(4-x) \mathrm{Si}^{4+} x \mathrm{Al}^{3+}$ & $4 \mathrm{Si}^{4+}$ \\
Interlayer & $2 \mathrm{Al}^{3+} 4 \mathrm{Mg}^{2+}$ & $2 x E^{+}$ & $2 y E^{+}$ \\
\hline
\end{tabular}

$x=$ tetrahedral substitution.

$y=$ octahedral substitution.

$E^{+}=$interlayer cation.

(*) Brindley (1980). 
migration of $\mathrm{Mg}$ as well as of $\mathrm{K}$. Consequently, sudoite crystallized from either smectite or solutions during burial conditions with both $\mathrm{Mg}$ concentration and $\mathrm{Mg} / \mathrm{K}$ ratio locally high.

The presence of chlorite as a diagenetic reaction product is primarily a function of $\mathrm{K}$ content (Whitney \& Northrop, 1988). For a low K content, both chlorite and quartz are produced in abundance from the bentonitic smectite when the latter reacts to I via an I-S intermediate phase (Whitney, personal communication). Secondary dolomitization is locally observed in the Dinantian limestones. However, the presence of sudoite is neither necessarily nor directly linked to the dolomitization as sudoite can be present in a bentonitic bed surrounded by limestone free of dolomite, or a K-bentonite without sudoite is interbedded in dolomitic rocks. Availability of $\mathrm{Mg}$ was not the unique factor that controlled the formation of sudoite. Circulation of $\mathrm{Mg}$-rich fluids has occurred as proved by the presence of dolomite, but conditions for fixation of $\mathrm{Mg}$ in the clay minerals and limestones may have been different.

In the Stavelot Massif, the pressure-temperature conditions in the shales enclosing the sudoite-bearing quartz veins have been estimated as $1-2$ kbars and $360-400^{\circ} \mathrm{C}$ (Kramm, 1980). In the Visean sediments, sudoite appears stable at lower pressure and temperature. Indeed, the presence of I-S with R1 and R3 ordering attests that the rocks have probably not been exposed to temperatures much greater than $200^{\circ} \mathrm{C}$ and pressures above 1 kbar. Furthermore, this paragenesis demonstrates that diagenetic sudoite formed at lower temperatures than pure illite (with $100 \% 10 \AA$ layers) (Weaver, 1989). Fransolet \& Schreyer (1984) have experimentally calculated the stability field of sudoite in the system $\mathrm{MgO}-\mathrm{Al}_{2} \mathrm{O}_{3}-\mathrm{SiO}_{2}-\mathrm{H}_{2} \mathrm{O}$ (MASH system); they suggested that sudoite may become unstable towards low temperatures (near $150-250^{\circ} \mathrm{C}$ ) (Fig. 7 in Fransolet \& Schreyer, 1984). With pressure and temperature probably below $1 \mathrm{kbar}$ and $200^{\circ} \mathrm{C}$, the sudoite in the Visean $\mathrm{K}$ bentonite beds is located near the lower limit of the stability field of sudoite. In their experiments, Fransolet \& Schreyer (1984) have worked with a total pressure equal to water pressure. During the diagenesis of Visean limestones and $\mathrm{K}$-bentonites, a partial $\mathrm{CO}_{2}$ pressure existed and influenced the evolution of the material. The influence of $\mathrm{p}_{\mathrm{CO}_{2}}$ on the appearance of sudoite in diagenetic conditions is not known, but a stabilization effect towards lower temperature is not impossible and could then explain the appearance and stability of the mineral at lower $\mathbf{P}$ and $\mathrm{T}$ conditions (Fransolet, personal communication). More data on the stability of sudoite in diagenetic and low-grade metamorphic conditions under partial carbon dioxide pressure are necessary to verify this hypothesis.

\section{COEXISTENCE OF SUDOITE AND PYRITE}

Diagenetic pyrite in the Visean K-bentonite beds provides evidence for the presence of $\mathrm{Fe}$ in the original material. Berner $(1984,1985)$ summarized the conditions of pyrite formation in sediments. During early diagenesis, bacterial sulphate reduction in limestone produced $\mathrm{H}_{2} \mathrm{~S}$ which reacted with $\mathrm{Fe}$ in the bentonites. This reaction took place below the sedimentwater interface, and produced iron sulphides. Berner (1984) noted that total Fe in sediment is rarely converted to pyrite. Depending upon $\mathrm{H}_{2} \mathrm{~S}$ concentrations, Fe-mineral reactivity, and time of reaction, the degree of pyritization of Fe never reaches $100 \%$. In the Visean rocks, the formation of pyrite during early diagenesis has consumed much of the Fe in the bentonite and the residual Fe became available for crystallization of chlorite. As there was not enough $\mathrm{Fe}$ for the diagenetic formation of the usual Fe-rich trioctahedral chlorite, the clay mineral coexisting with pyrite in the $\mathrm{K}$-bentonites is an Fe-poor chlorite, a sudoite. 


\section{CONCLUSIONS}

Visean K-bentonites resulted from the alteration of volcanic ash deposited in a marine carbonate environment. The halmyrolytic alteration has transformed the volcanic deposit into a clayey material originally dominated by a smectitic component. With increasing burial, smectite was transformed into I-S mixed-layers. The chlorite present in some beds as a minor or a major component of the clay matrix is a sudoite, poor in $\mathrm{Fe}$, and occurring rarely during diagenetic conditions. The chemical composition and crystallographic properties of this mineral have been determined from a K-bentonite sample composed of pure sudoite. The genetic pathway of this mineral in the Visean K-bentonites is not completely resolved but some hypotheses have been proposed. The formation of sudoite, and not of a Fe-rich chlorite as usually found through diagenesis, could be related to an early pyrite which crystallized before sudoite. On the other hand, the association of sudoite and of an ordered I-S in the same bed suggests that sudoite is stable at $\mathrm{P}, \mathrm{T}$ conditions lower than those characteristic for the development of a pure illite (with $100 \% 10 \AA$ layers) i.e. before low-grade metamorphic conditions were reached.

\section{ACKNOWLEDGMENTS}

The author is indebted to B. Delcambre (Louvain-la-Neuve University) for continuous assistance in the study of Visean K-bentonite outcrops. Thanks are also due to Professors J. Thorez, A.-M. Fransolet, and E. Poty (Liège University) for helpful discussions and critical reading of the manuscript. Gratitude is expressed to Dr J. Srodon (Krakow) for improving the original manuscript and for constructive suggestions.

\section{REFERENCES}

Arrn J.H. \& Buseck P.R. (1988) Al-chlorite as a hydration reaction product of andalusite: a new occurrence. Mineral. Mag. 52, 396-399.

Appleman D.E. \& Evans H.T., JR. (1973) Indexing and Least-Squares Refinement of Powder Diffraction Data. Report PB216188. US Dept. of Commerce, National Technical Information Service, Springfield, VA 22151.

BaILEY S.W. (1980a) Summary of recommendations of the A.I.P.E.A. nomenclature committee. Can. Mineral. 18, $143-150$.

Barley S.W. (1980b) Structures of layer silicates. Pp. 1-123 in: Crystal Structures of Clay Minerals and their X-ray Identification (G.W. Brindley \& G. Brown, editors). Mineralogical Society, London.

Barley S.W. (1988) Chlorites: structures and crystal chemistry. Pp. 347-403 in: Hydrous Phyllosilicates (Exclusive of Micas) (S.W. Bailey, editor). Reviews in Mineralogy, vol. 19. Mineralogical Society of America, Washington, DC.

Balley S.W. \& LISTER J.S. (1989) Structures, compositions, and X-ray diffraction identification of dioctahedral chlorites. Clays Clay Miner. 37, 193-202.

Bailey S.W., Brindley G.W., Kodama H. \& Martin R.T. (1979) Report of the Clay Minerals Society Nomenclature Committee for 1977 and 1978. Clays Clay Miner. 27, 238-239.

Berner R.A. (1984) Sedimentary pyrite formation: An update. Geochim. Cosmochim. Acta 48, 605-615.

Berner R.A. (1985) Sulphate reduction, organic matter decomposition and pyrite formation. Pp. 25-38 in: Geochemistry of Buried Sediments (G. Eglinton, C.D. Curtis, D.P. McKenzie \& D.G. Murchison, editors). Phil. Trans. Roy. Soc. Lond. A315, London.

BRINDley G.W. (1980) Order-disorder in clay mineral structures. Pp. 125-195 in: Crystal Structures of Clay Minerals and their X-ray Identification (G.W. Brindley \& G. Brown, editors). Mineralogical Society, London.

Conil R., Groessens E. \& Pirlet H. (1977) Nouvelle charte stratigraphique du Dinantien type de la Belgique. Ann. Soc. Géol. Nord XCVI, 363-371.

Dixon J.B. \& JACKson M.L. (1960) Mineralogical analysis of soil clays involving vermiculite-chlorite-kaolinite differentiation. Clays Clay Miner. 8, 274-286.

Eberl D.D. \& Velde B. (1989) Beyond the Kubler index. Clay Miner. 24, 571-577.

Eggleton R.A. \& Bailey S.W. (1967) Structural aspects of dioctahedral chlorite. Am. Miner. 52, 673-689. 
Fransolet A.-M. \& Bourguignon P. (1978) Di/trioctahedral chlorite in quartz veins from the Ardenne, Belgium. Can. Mineral. 16, 365-373.

Fransolet A.-M. \& Schreyer W. (1984) Sudoite, di/trioctahedral chlorite: a stable low-temperature phase in the system $\mathrm{MgO}-\mathrm{Al}_{2} \mathrm{O}_{3}-\mathrm{SiO}_{2}-\mathrm{H}_{2} \mathrm{O}$. Contr. Miner. Petrol. 86, 409-417.

Hower J., Eslinger E.V., Hower M.E. \& Perry E.A. (1976) Mechanism of burial metamorphism of argillaceous sediment: 1. Mineralogical and chemical evidence. Geol. Soc. Am. Bull. 87, 725-737.

Kramm U. (1980) Sudoite in low-grade metamorphic manganese rich assemblages. N. Jb. Miner. Abh. 138, 1-13.

LiN C.-Y. \& Bailey S.W. (1985) Structural data for sudoite. Clays Clay Miner. 33, 410-414.

Mehra O.P. \& JACKSON M.L. (1960) Iron oxide removal from soils and clays by a dithionite-citrate system buffered with sodium bicarbonate. Clays Clay Miner. 7, 317-327.

Moore D.M. \& ReYnolds R.C. JR. (1989) X-ray Diffraction and the Identification and Analysis of Clay Minerals, pp. 146-147. Oxford University Press.

Percival J.B. \& Kodama H. (1989) Sudoite from Cigar Lake. Saskatchewan. Can. Mineral. 27, 633-641.

Środoń J. (1984) X-ray powder diffraction identification of ilitic materials. Clays Clay Miner. 32, 337-349.

Środoń J. \& EberL D.D. (1984) Illite. Pp. 495-544 in: Micas (S.W. Bailey, editor). Reviews in Mineralogy, vol. 13. Mineralogical Society of America, Washington, DC.

Sudo T. \& Sato M. (1966) Dioctahedral chlorite. Proc. Int. Clay Conf. Jerusalem, 1, 33-39; 2, 25-26.

Thorez J. \& Pirlet H. (1978) Petrology of K-bentonite bed; in the carbonates series of the Visean and Tournaisian stages of Belgium. Proc. 6th Int. Clay Conf., Oxford, 323-332.

UNGETHÜM H. (1965) Eine neue Methode zur Bestimmung von Eisen (II) in Gesteinen und Mineralen, insbesondere auch in bitumenhaltigen Problem. Zeit. für angewandte Geol. 11, 500-505.

Weaver C.E. (1953) Mineralogy and petrology of some Ordovician K-bentonites and related limestones. Bull. Geol. Soc. Am. 64, 921-944.

WeAver C.E. (1959) The clay petrology of sediments. Clays Clay Miner. 6, 154-187.

Weaver C.E. (1989) Clays, Muds, and Shales. (Developments in Sedimentology 44). Elsevier, Amsterdam.

WhITNEY G. \& NorThrop H.R. (1988) Experimental investigation of the smectite to illite reaction: Dual reaction mechanisms and oxygen-isotope systematics. Am. Miner. 73, 77-90. 